\title{
OPTIMIZATION OF SPRAY-DRYING PARAMETERS FOR 'BINTANGOR' ORANGE (CITRUS RETICULATA BLANCO X CITRUS AURANTIUM L.) JUICE
}

\author{
Yu, L.M. ${ }^{1}$ and Pui, L.P. ${ }^{1 凶}$ \\ ${ }^{1}$ Department of Food Science with Nutrition, Faculty of Applied Sciences, UCSI University, No. 1, Jalan \\ Menara Gading, UCSI Heights, 56000 Cheras, Kuala Lumpur, Malaysia. \\ هuilp@ucsiuniversity.edu.my \\ https://doi.org/10.34302/crpjfst/2021.13.1.13 \\ Article history: \\ Received: \\ 27 April 2020 \\ Accepted: \\ 25 February 2021 \\ Keywords: \\ Spray-drying; \\ Orange; \\ Maltodextrin; \\ Inlet temperature; \\ Physicochemical properties.

\begin{abstract}
'Bintangor' orange is a type of mandarin-orange hybrid, that has orangecolored pulp, but green-colored peel. The objective of this study was to determine the effects of maltodextrin concentrations ( $5 \% \mathrm{w} / \mathrm{w}$ to $25 \% \mathrm{w} / \mathrm{w})$ and inlet temperatures $\left(140^{\circ} \mathrm{C}\right.$ to $\left.180^{\circ} \mathrm{C}\right)$ on the properties of spray-dried 'Bintangor' orange powder. Color, moisture content, hygroscopicity, bulk density and wettability of powder were analyzed. Also, 'Bintangor' orange juice and the reconstituted powder were compared in color, viscosity, total soluble solids (TSS), and $\mathrm{pH}$ value. When 'Bintangor' orange juice was spray-dried with different maltodextrin concentrations, moisture content, color, hygroscopicity, bulk density and wettability increases as the maltodextrin concentration increase. On the other hand, there was no significant difference $(\mathrm{p}>0.05)$ in the color, moisture content, and hygroscopicity of spray-dried 'Bintangor' orange powder produced at different inlet temperatures, except bulk density. Optimum inlet temperature $\left(170^{\circ} \mathrm{C}\right)$ and optimum maltodextrin concentration $(20 \% \mathrm{w} / \mathrm{w})$ produced powder with $0.11 \pm 0.00$ water activity and $20.02 \pm 1.00 \mathrm{~g} / 100 \mathrm{~g}$ hygroscopicity. When comparing reconstituted optimized powder with 'Bintangor' orange juice, the color, viscosity, TSS, and $\mathrm{pH}$ value of 'Bintangor' orange juice were higher than the optimized reconstituted powder. 'Bintangor' orange powder produced have $2.21 \pm 1.91 \%$ fat, and $2.44 \pm 0.00 \%$ protein.
\end{abstract}

\section{Introduction}

Mandarin is one type of commercial citrus fruit that belongs to the separate species, hybrids that are available worldwide (Laszlo, 2008). It is well known for Mandarins are well known for their attractive appearance, pleasant taste, and convenience due to easy peeling characteristics (Rizza et al., 2002). Besides, vitamin $\mathrm{C}$ and flavonoids in the citrus juice are providing good health effects to our body, such as anti-allergic and anticarcinogenic (Ladanyia and Ladaniya, 2010). Mandarin is a seasonal fruit that is not available throughout the year, like oranges (Jackson et al., 2011). 'Bintangor' orange is believed to be one of the hybrids between common mandarin and bitter orange, which is a hybrid between Citrus reticulata Blanco with Citrus aurantium L. (Urgi, 2014). The flesh of the 'Bintangor' orange is more sour and bitter taste than the other mandarin species. It is more prone to damage as they have thinner and looser skins. In addition, with shorter shelf life, there is a need to convert the fruit into more stable products such as fruit powder, which has a lower moisture content (Phisut, 2012). 
In addition to food preservation, drying can help to minimize the packaging requirement, reduce the shipping costs, and makes the food supply more economical (Hui et al., 2010). Among different drying methods, spray-drying has been employed in the drying of liquid suspensions such as dairy products, coffee, eggs, protein, and fruit juice (Karel and Lund, 2003). Spray-drying is the technique which is usually used to produce the fruit juice powder (Chew et al., 2019), this includes watermelon, acai, pineapple, orange, blackberry, pomegranate, mango, and jackfruit (Quek et al., 2007; Angel et al., 2009; Tonon et al., 2010; Jittanit et al., 2010; Goula and Adamopoulos, 2010; Ferrari et al., 2012; Chng et al., 2020; Pui et al., 2020a).

However, the physicochemical properties of the final product obtained will depend on the parameter of spray-drying such as types and concentration of carrier agent, inlet temperature, airflow rate, feed flow rate, and atomizer speed (Phisut, 2012). Fruit powder, when spray-dried without a carrier, has a low glass transition temperature. Besides that, the product will also have an unfavorable characteristic such as high hygroscopicity, low melting point, and high-water solubility, which in turn results in a highly sticky product (Angel et al., 2009; Jittanit et al., 2010). Hence, carrier agents such as maltodextrin, waxy starch, liquid glucose and microcrystalline cellulose and Arabic gum were added to facilitate the drying process, reducing the stickiness and hygroscopicity of the powder (Phoungchandang and Sertwasana, 2010; Phisut, 2012). Among these carrier agents, maltodextrin is the most common carrier agent had used for spray-drying as it is considered cheaper and has high water solubility (Tuyen et al., 2010; Jittanit et al., 2010). Spray-drying with maltodextrin as a carrier has been used to convert juice from tropical fruit such as 'Terung Asam', papaya, pineapple, 'Cempedak' and 'Kuini' (Chang et al., 2020a; Chang et al., 2020b; Wong et al. 2015, Gopinathan et al., 2020; Gan et al., 2021).
Hence, this research aims to work on the spray-drying of mandarin juice in producing mandarin powder. This research will work on the effect of different concentrations of maltodextrin as carrier agents, and the effect of different inlet temperatures on the production of mandarin powder. Besides that, the physicochemical properties and also the proximate compositions of the spray-dried mandarin powder and reconstituted powder will be investigated.

\section{Materials and methods}

\subsection{Materials}

\subsubsection{Fruit samples}

The fruit that is used in this study was 'Bintangor' orange. Figure 1 shows the fresh 'Bintangor' orange and the peeled 'Bintangor' orange. These oranges were bought from the local market in Sibu, Sarawak. The selected oranges were free from external defects and were uniform in size $(6.0 \mathrm{~cm}$ to $6.5 \mathrm{~cm}$ in diameter). The 'Bintangor' orange juice was extracted, and physicochemical properties (color, viscosity, total soluble solids (TSS), and pH) determined. 2.2.1 Color

The color of the 'Bintangor' orange juice was analyzed, according to Chang et al. (2020a), by using a colorimeter (ColorFlex Ez, Hunter Associates Laboratory Inc., USA), equipped with EasyMatch QC-ER software. Standardization was conducted using black tile first and followed by white tile. The juice was poured into the Quartz sample cup and placed on top of the sample port, covered, and measurements were taken. The values were expressed in terms of $\mathrm{L}^{*}, \mathrm{a}^{*}$, and $\mathrm{b}^{*}$.

\subsubsection{Viscosity}

The viscosity of the samples was analyzed according to Grabowski et al. (2006) with a viscometer (DV-II+ Pro, Brookfield, USA) coupled with Rheocale software program and Ultra Lower Adapter (ULA) spindle. Juice (15 $\mathrm{mL}$ ) was poured into the sample tube, and measurements were taken at a rotational speed of $100 \mathrm{rpm}$. 


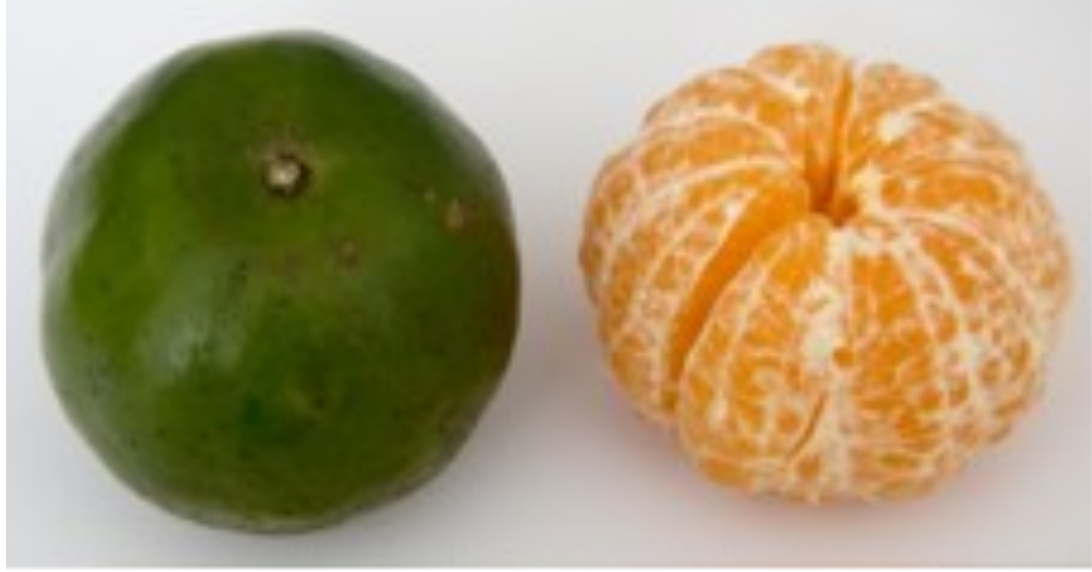

Figure 1. Fresh 'Bintangor' orange (left) and peeled 'Bintangor' orange (right).

\subsection{Analysis of 'Bintangor' orange juice}

\subsubsection{Total soluble solid (TSS) and $\mathrm{pH}$ value}

Total soluble solids (TSS) of the samples were measured with a digital refractometer (MA 871, Milwaukee Instrument, USA), (0- 85 ${ }^{\circ}$ Brix range) (Pui et al., 2018). On the other hand, the $\mathrm{pH}$ values of the samples were measured with a digital $\mathrm{pH}$ meter (Jenway, UK) (Pui et al., 2020b).

\subsection{Spray-drying of 'Bintangor' orange juice}

The spray-drying process was performed with mini spray-dryer (B-290, Büchi, Switzerland) (Loo and Pui, 2020). The setting was fixed at aspirator rate $100 \%$, nozzle speed 5, and air compressor $40 \mathrm{~nm}$. Maltodextrin was added into juice at different concentrations of $5,10,15,20$, and $25 \%(\mathrm{w} / \mathrm{w})$, respectively, with a spray-drying temperature fixed at $180^{\circ} \mathrm{C}$.

The 'Bintangor' orange powders were recovered in the vessel, which is the collecting area of the spray-dryer. It was collected, weighed, and vacuum packed immediately. The weight of the spray-dried powders, total time taken, and also the condition of powders was recorded for spray-drying of each inlet temperature. Physicochemical analyses and the reconstitution properties of spray-dried powders were performed after all the spraydried powders with different inlet temperatures were collected.
The spray-drying process was repeated to determine the effect of inlet temperature (140, $150,160,170$, and $180^{\circ} \mathrm{C}$ ) used in the production of 'Bintangor' orange powder, with maltodextrin concentration fixed at $20 \%$ (w/w).

\subsection{Physicochemical analyses of spray-dried 'Bintangor' orange powder}

\subsubsection{Color}

The color determination of the 'Bintangor' orange powders was conducted, according to Chang et al. (2020a).

\subsubsection{Moisture content}

The moisture content of the 'Bintangor' orange powders was determined, according to AOAC (2000). Approximately 2 grams of the powders were weighed into the pre-dried aluminum plates before drying at $105^{\circ} \mathrm{C}$ for 24 hours (Memmert, Germany). The readings of powders were collected after a constant weight was obtained.

\subsubsection{Hygroscopicity}

'Bintangor' orange powders (2 g) was placed in a desiccator containing saturated ammonium sulfate at room temperature for 1 week. The hygroscopicity of the powders was calculated by using the following equation (Cai and Corke, 2000):

Equation 1

Hygroscopicity $(\mathrm{g} / 100 \mathrm{~g})=($ Weight of sample after a week (g)- Initial Weight of sample $(\mathrm{g})) /($ Initial weight of sample $(\mathrm{g})) \times 100$. 


\subsubsection{Bulk density}

'Bintangor' orange powder (5 g) was transferred into a $20 \mathrm{~mL}$ measuring cylinder and tapped by hand for 5 times. The volume occupied that was recorded, and bulk density was calculated according to equation 2 (Tonon et al., 2011). Bulk density was expressed in grams per milliliter $(\mathrm{g} / \mathrm{mL})$.

\section{Equation 2}

Bulk density $(\mathrm{BD})=$ (Weight of powder $(\mathrm{g})) /($ Volume of powder $(\mathrm{mL}))$.

\subsubsection{Wettability}

The wettability of the 'Bintangor' orange powder was determined according to Chauhan and Patil (2013). 'Bintangor' orange powder (1 g) was spread about $6 \mathrm{~cm}$ (in diameter) on a cloth, and the time for the powder to be completely wet as recorded.

\subsection{Physicochemical analyses of reconstituted 'bintangor' orange powder}

The spray-dried 'Bintangor' orange powder was added with water, to a similar total soluble solid (TSS) content as the 'Bintangor' orange fruit juice (Pui et al., 2021). 'Bintangor' orange powder ( $5 \mathrm{~g}$ ) was added with warm water (45 $\mathrm{g})$, stirred until all powder is dissolved. This is followed by the gradual addition of powder until TSS is reached. Analysis such as color, $\mathrm{pH}$, and viscosity, were carried out on reconstituted powders.

\subsection{Proximate analysis of spray-dried 'Bintangor' orange powder}

The proximate analyses for ash, fat and protein of spray-dried 'Bintangor' orange powder were determined according to the Association of Official Analytical Chemists (AOAC) methods (2000) with some modifications.

\subsection{Statistical Analysis}

All the experiments were carried out in triplicate $(n=3)$. The data collected was expressed in terms of mean \pm standard deviations. All the data in the analysis of powder were analyzed by One-Way ANOVA (IBM SPSS software 22). The significant differences at $\mathrm{p} \leq 0.05$ were determined by Tukey's test (Chng et al., 2020). On the other hand, paired-samples T-test was used to compare the physicochemical analyses between 'Bintangor' orange juice and optimized reconstituted 'Bintangor' orange powder.

\section{Results and discussions}

\subsection{Physicochemical properties of 'bintangor' orange juice}

Table 1 showed the physicochemical properties of the 'Bintangor' orange juice used for the spray-drying process, including color measurement, $\mathrm{pH}$ values total soluble solid (TSS), and viscosity. The lightness (L*), redness $\left(\mathrm{a}^{*}\right)$, and yellowness $\left(\mathrm{b}^{*}\right)$ of the 'Bintangor' orange juice were $47.92 \pm 1.46$, $10.44 \pm 0.33$ and $38.53 \pm 0.88$, respectively. When compared to the fresh orange juice in Cortés et al. (2008), the lightness and yellowness of the fresh orange juice were slightly higher than the 'Bintangor' orange juice which was 51.36 and 50.73 , respectively, while the redness of the orange juice was slightly lower than the 'Bintangor' orange juice which was 4.56 . This can be possibly explained as the growing environment and the ripeness of the mandarin tree (Ladanyia and Ladaniya, 2010). Besides that, the viscosity of 'Bintangor' orange juice recorded in Table 1 was $4.87 \pm 0.60$ centiPoise (cP). This viscosity is low enough to prevent clogging in the atomizer during the spray-drying process (Chegini and Ghobadian, 2007; Phisut, 2012).

From Table 1, the total soluble solids (TSS) of the 'Bintangor' orange juice was $12.00 \pm 0.35$ ${ }^{\circ}$ Brix, while the TSS for the other types of mandarin was around 12.5-14.5 ${ }^{\circ}$ Brix (Roussos et al., 2011). This TSS was slightly lower than the other types of mandarins. This difference may due to different species of mandarins have different types of breeding goals. Hence, there will be some differences in the quality of different species of mandarin (Jenks and Bebeli, 2011). 
Table 1. Physicochemical properties of 'Bintangor' orange juice (spray-dryer feeds)

\begin{tabular}{|c|c|}
\hline Properties & Values \\
\hline $\mathrm{L}^{*}$ value & $47.92 \pm 1.46$ \\
\hline $\mathrm{a}^{*}$ value & $10.44 \pm 0.33$ \\
\hline $\mathrm{b}^{*}$ value & $38.53 \pm 0.88$ \\
\hline Viscosity (cP) & $4.87 \pm 0.60$ \\
\hline Total soluble solids, TSS ( ${ }^{\circ}$ Brix) & $12.00 \pm 0.35$ \\
\hline $\mathrm{pH}$ & $4.29 \pm 0.03$ \\
\hline
\end{tabular}

Data on TSS, $\mathrm{pH}$, viscosity, and color are means \pm standard deviations of triplicate determination. Abbreviations: TSS $=$ total soluble solid, ${ }^{\circ} \mathrm{Brix}=$ degree $\mathrm{Brix}, \mathrm{pH}=$ potential of hydrogen, $\mathrm{cP}=$ centipoise, $\mathrm{L}^{*}=$ degree of lightness and darkness, $\mathrm{a}^{*}=$ degree of redness or greenness and $\mathrm{b}^{*}=$ degree of yellowness or blueness.

The $\mathrm{pH}$ value was less susceptible to microbial growth as the value lower than 4.5 is considered as a low acid fruit (Chukwuka et al., 2010). However, the $\mathrm{pH}$ value of 'Bintangor' orange juice was higher than the other species of mandarins like Clementine, Encore, and Kara, which are ranged from 3.71 to 3.86 (Roussos et al., 2011). This may be attributed to the different environment for mandarin growing (Ladanyia and Ladaniya, 2010). Besides the environment, the storage temperature and time also can influence the sensory quality of mandarins such as TSS, acidity, and aroma volatile composition (Sinha et al., 2012).

\subsection{Effect of maltodextrin concentration on physicochemical analyses of spray-dried 'Bintangor' orange powder}

The physicochemical analyses of spraydried 'Bintangor' orange powder at different maltodextrin concentrations were exhibited in Table 2.

$\mathrm{L}^{*}$ value of spray-dried powder was ranged from $87.45 \pm 1.02$ to $92.71 \pm 0.45$, and $\mathrm{a}^{*}$ value was ranged from $2.75 \pm 0.21$ to $6.18 \pm 0.56$. Besides that, the $b^{*}$ value of the spray-dried 'Bintangor' orange powder was ranged from $14.28 \pm 0.67$ to $27.63 \pm 0.48$. All $\mathrm{L}^{*}$ values in the table were close to 100 . Hence, it can be said that the spray-dried 'Bintangor' orange powders appeared to be lighter or brighter in color. The $\mathrm{L}^{*}$ value increased from the lowest value at $5 \%(\mathrm{w} / \mathrm{w})$ concentration, which was $87.45 \pm 1.02$ to the highest value at $25 \%(\mathrm{w} / \mathrm{w})$ maltodextrin concentration, which was $92.71 \pm 0.45$. The possible explanation for the increase of value is due to the addition of maltodextrin, which is whitish, which affects the lightness of the spray-dried powder (Tuyen et al., 2010).

Table 2. Physicochemical analyses of spray-dried 'Bintangor' orange powder under different maltodextrin concentrations of maltodextrin

\begin{tabular}{|c|c|c|c|c|c|c|c|}
\hline $\begin{array}{c}\text { Maltodextrin } \\
\text { concentration } \\
(\mathrm{w} / \mathrm{w})\end{array}$ & Color $\left(\mathrm{L}^{*}\right)$ & Color $\left(\mathrm{a}^{*}\right)$ & Color $\left(\mathrm{b}^{*}\right)$ & $\begin{array}{c}\text { Moisture } \\
\text { content } \\
(\%)\end{array}$ & $\begin{array}{c}\text { Hygroscopicity } \\
(\mathrm{g} / 100 \mathrm{~g})\end{array}$ & $\begin{array}{c}\text { Bulk } \\
\text { density } \\
(\mathrm{g} / \mathrm{mL})\end{array}$ & $\begin{array}{c}\text { Wettability } \\
(\mathrm{secs})\end{array}$ \\
\hline 5 & $87.45 \pm 1.02^{\mathrm{a}}$ & $6.18 \pm 0.56^{\mathrm{a}}$ & $27.63 \pm 0.48^{\mathrm{a}}$ & $7.39 \pm 1.03^{\mathrm{a}}$ & $29.09 \pm 0.79^{\mathrm{a}}$ & $0.37 \pm 0.01^{\mathrm{a}}$ & $112.56 \pm 6.50^{\mathrm{a}}$ \\
\hline 10 & $90.63 \pm 0.66^{\mathrm{b}}$ & $3.88 \pm 0.40^{\mathrm{b}}$ & $19.92 \pm 0.88^{\mathrm{b}}$ & $6.03 \pm 0.35^{\mathrm{ab}}$ & $25.02 \pm 0.06^{\mathrm{b}}$ & $0.45 \pm 0.03^{\mathrm{b}}$ & $125.22 \pm 4.02^{\mathrm{a}}$ \\
\hline 15 & $91.54 \pm 0.32^{\mathrm{c}}$ & $3.40 \pm 0.21^{\mathrm{bc}}$ & $17.33 \pm 0.64^{\mathrm{c}}$ & $3.81 \pm 0.99^{\mathrm{bc}}$ & $22.99 \pm 0.37^{\mathrm{c}}$ & $0.49 \pm 0.03^{\mathrm{b}}$ & $149.22 \pm 5.67^{\mathrm{b}}$ \\
\hline 20 & $92.22 \pm 0.29^{\mathrm{bc}}$ & $2.99 \pm 0.09^{\mathrm{bc}}$ & $15.54 \pm 0.67^{\mathrm{cd}}$ & $2.43 \pm 0.78^{\mathrm{c}}$ & $21.64 \pm 0.43^{\mathrm{d}}$ & $0.48 \pm 0.03^{\mathrm{b}}$ & $166.78 \pm 5.19^{\mathrm{c}}$ \\
\hline 25 & $92.71 \pm 0.45^{\mathrm{c}}$ & $2.75 \pm 0.21^{\mathrm{c}}$ & $14.28 \pm 0.67^{\mathrm{d}}$ & $2.38 \pm 0.85^{\mathrm{c}}$ & $20.79 \pm 0.49^{\mathrm{d}}$ & $0.48 \pm 0.03^{\mathrm{b}}$ & $177.22 \pm 3.35^{\mathrm{c}}$ \\
\hline
\end{tabular}

Data on all analyses are means \pm standard deviations of triplicate determination. Within the same column, different superscripts are significantly different at $p \leq 0.05$, as measured by Tukey's test. Abbreviations: $\%=$ percent, $L^{*}=$ degree of lightness, $\mathrm{a}^{*}=$ degree of redness, $\mathrm{b}^{*}=$ degree of yellowness, $\mathrm{g} / \mathrm{mL}=$ gram per milliliter, $\mathrm{g} / 100 \mathrm{~g}=$ gram per $100 \mathrm{~g}$, and secs $=$ seconds. 
In Table 2, there was a significant effect ( $p$ $\leq 0.05)$ of maltodextrin concentration on the value of $a^{*}$ and $b^{*}$ of the spray-dried 'Bintangor' orange powder. All a* value obtained were in positive. The $\mathrm{a}^{*}$ value, indicating the 'Bintangor' orange powder's redness, decreased from maltodextrin concentration of $5 \%(\mathrm{w} / \mathrm{w})$ to $25 \%(\mathrm{w} / \mathrm{w})$. The positive $a^{*}$ value indicates the powders are more in red color and less in green color. The $\mathrm{b}^{*}$ values in the table were also in positive value, where it is increased from $5 \%(\mathrm{w} / \mathrm{w})$ concentration of maltodextrin to $25 \%(\mathrm{w} / \mathrm{w})$ concentration of maltodextrin. All powders obtained are yellowish, as all the $b^{*}$ values are in positive value. As mentioned by Tuyen et al. (2010), the color intensity of the spray-dried powder was lost due to increase concentration maltodextrin.

The moisture content of spray-dried powder at $5 \%(\mathrm{w} / \mathrm{w})$ maltodextrin was $7.39 \pm 1.03 \%$, decreased to $6.03 \pm 035 \%$ and $3.81 \pm 0.99 \%$, respectively with the addition of maltodextrin at $10 \%(\mathrm{w} / \mathrm{w})$ and $15 \%(\mathrm{w} / \mathrm{w})$. It was further decreased to $2.43 \pm 0.78 \%$ and $2.38 \pm 0.85 \%$ for spray-dried powder with $20 \%(\mathrm{w} / \mathrm{w})$ and $25 \%$ $(\mathrm{w} / \mathrm{w})$ concentration of maltodextrin, respectively. The moisture content was in agreement with Jittanit et al. (2010) and Tuyen et al. (2010), who reported the range of $4-4.8 \%$ and 4.06-4.87 pineapple and gac fruit. Besides that, Quek et al. (2007) also reported that powders with lower moisture content could be obtained by increasing the concentration of maltodextrin added.

When the maltodextrin concentration increases, maltodextrin addition to the feed will increase the total solid content, leading to a reduction in the amount of water for evaporation. This, in turn, will lead to a decrease in moisture content (Quek et al., 2007). In addition, maltodextrin covers the sugars content, which is highly hygroscopic in the powder, thus reducing the ability to absorb the humidity in the surrounding air (Phoungchandang and Sertwasana, 2010; Phisut, 2012). Hence, decreasing moisture content in the powder cause the powder less likely to get sticky as the maltodextrin concentration increases.

According to Table 2, it was found that there was a reduction of hygroscopicity of spray-dried powder with $5 \%(\mathrm{w} / \mathrm{w})$ to $25 \%$ $(\mathrm{w} / \mathrm{w})$ maltodextrin concentration, which was reduced from $0.79 \mathrm{~g} / 100 \mathrm{~g}$ to $29.09 \pm 0.79 \mathrm{~g} / 100$ g. Maltodextrin is a material with low hygroscopicity (Tuyen et al., 2010). When it acts as the coating agent, it could reduce the hygroscopicity of the spray-dried powder (Cai and Corke, 2000).

The bulk density of the spray-dried 'Bintangor' orange powder obtained with different concentrations of maltodextrin can be observed in Table 2 . The bulk density of spraydried powder varied from $0.37 \pm 0.01 \mathrm{~g} / \mathrm{mL}$ to $0.49 \pm 0.03 \mathrm{~g} / \mathrm{mL}$, which are achieved by addition of $5 \%(\mathrm{w} / \mathrm{w})$ concentration and $15 \%$ $(\mathrm{w} / \mathrm{w})$ concentration of maltodextrin added, respectively. However, bulk density of spraydried powder with $20 \%(\mathrm{w} / \mathrm{w})$ and $25 \%(\mathrm{w} / \mathrm{w})$ maltodextrin added decreased to $0.48 \pm 0.03$ $\mathrm{g} / \mathrm{mL}$. This is because maltodextrin added can minimize the thermoplastic particles from sticking (Goula and Adamopoulos, 2010).

From Table 2, it can be observed that the wettability of the spray-dried powder was decreased from $112.56 \pm 6.50$ seconds to $177.22 \pm 3.35$ seconds. 'Bintangor' orange powder with $5 \%(\mathrm{w} / \mathrm{w})$ maltodextrin have the highest wettability value $(112.56 \pm 6.50$ seconds), while with $25 \%(\mathrm{w} / \mathrm{w})$ maltodextrin, it has the lowest value (177.22 \pm 3.35 seconds). Wettability can be defined as the ability of a powder to be penetrated by a liquid. The wettability value is higher than those of blackberry powder $(82.20 \pm 12.30$ seconds to $134.20 \pm 12.52$ seconds). With higher wettability value, a longer time is needed to wet the powder. This may be due to smaller particles are less porous, making it difficult for liquid penetration to happen. It will result in poor reconstitution properties (Ferrari et al., 2012).

The spray-dried powder with $20 \%(\mathrm{w} / \mathrm{w})$ maltodextrin concentration achieved the lowest bulk density value and the highest $\mathrm{L}^{*}$ value, which were $0.48 \pm 0.03 \mathrm{~g} / \mathrm{mL}$ and $92.22 \pm 0.29$ 
$\mathrm{g} / \mathrm{mL}$, respectively. For the moisture content, the spray-dried powder with $25 \% \quad(\mathrm{w} / \mathrm{w})$ maltodextrin achieved the lowest value. However, there was no significant difference ( $p>0.05$ ) between the moisture content of $20 \%$ $(\mathrm{w} / \mathrm{w})$ and $25 \%(\mathrm{w} / \mathrm{w})$ concentration. The value of the moisture content for $20 \% \quad(\mathrm{w} / \mathrm{w})$ maltodextrin concentration was $2.43 \pm 0.78 \%$. Apart from that, the water activity of the spraydried powder with $20 \%(\mathrm{w} / \mathrm{w})$ maltodextrin concentration achieved the lowest value, which is $0.08 \pm 0.01$.

\subsection{Effect of inlet temperature on Physicochemical analyses of spray-dried 'Bintangor' orange powder}

Table 3 describes the physicochemical analyses of spray-dried 'Bintangor' orange powder at different inlet temperatures ranged from $140^{\circ} \mathrm{C}$ to $180^{\circ} \mathrm{C}$ under $20 \% \quad(\mathrm{w} / \mathrm{w})$ maltodextrin concentration. From Table 3, there was no significant difference $(p>0.05)$ observed for all the physicochemical analyses except bulk density. In Table 3 , it can be observed $L^{*}$ values, $a^{*}$ and $b^{*}$ value of 'Bintangor' orange powder were in the range of 92.23-92.81, 1.76-1.98, and 13.99-15.05, respectively. The powders have low moisture contents $(2.82-3.66 \%)$, the hygroscopicity of $20.02-20.85 \mathrm{~g} / 100 \mathrm{~g}$ and wettability of 198 to $220 \mathrm{sec}$.

Table 3. Physicochemical analyses of spray-dried 'Bintangor' orange powder with optimum maltodextrin concentration at different inlet temperatures

\begin{tabular}{|c|c|c|c|c|c|c|c|}
\hline $\begin{array}{c}\text { Inlet } \\
\text { temperature } \\
\left({ }^{\circ} C^{)}\right.\end{array}$ & Color $\left(\mathrm{L}^{*}\right)$ & Color $\left(\mathrm{a}^{*}\right)$ & Color $\left(\mathrm{b}^{*}\right)$ & $\begin{array}{c}\text { Moisture } \\
\text { content } \\
(\%)\end{array}$ & $\begin{array}{c}\text { Hygroscopicity } \\
(\mathrm{g} / 100 \mathrm{~g})\end{array}$ & $\begin{array}{c}\text { Bulk } \\
\text { density } \\
(\mathrm{g} / \mathrm{mL})\end{array}$ & $\begin{array}{c}\text { Wettability } \\
(\mathrm{secs})\end{array}$ \\
\hline 140 & $92.27 \pm 0.27^{\mathrm{a}}$ & $1.92 \pm 0.29^{\mathrm{a}}$ & $13.99 \pm 0.44^{\mathrm{a}}$ & $3.66 \pm 0.61^{\mathrm{a}}$ & $20.77 \pm 1.53^{\mathrm{a}}$ & $0.48 \pm 0.01^{\mathrm{b}}$ & $198.33 \pm 0.58^{\mathrm{a}}$ \\
\hline 150 & $92.49 \pm 0.13^{\mathrm{a}}$ & $1.88 \pm 0.14^{\mathrm{a}}$ & $14.51 \pm 0.37^{\mathrm{a}}$ & $3.27 \pm 0.42^{\mathrm{a}}$ & $20.85 \pm 0.64^{\mathrm{a}}$ & $0.49 \pm 0.00^{\mathrm{bc}}$ & $198.33 \pm 0.58^{\mathrm{a}}$ \\
\hline 160 & $92.81 \pm 0.17^{\mathrm{a}}$ & $1.76 \pm 0.23^{\mathrm{a}}$ & $14.43 \pm 0.85^{\mathrm{a}}$ & $3.00 \pm 0.50^{\mathrm{a}}$ & $20.71 \pm 0.75^{\mathrm{a}}$ & $0.46 \pm 0.00^{\mathrm{a}}$ & $205.89 \pm 0.19^{\mathrm{a}}$ \\
\hline 170 & $92.44 \pm 0.10^{\mathrm{a}}$ & $1.98 \pm 0.26^{\mathrm{a}}$ & $15.48 \pm 0.90^{\mathrm{a}}$ & $2.88 \pm 0.50^{\mathrm{a}}$ & $20.02 \pm 1.00^{\mathrm{a}}$ & $0.50 \pm 0.01^{\mathrm{c}}$ & $211.11 \pm 1.50^{\mathrm{a}}$ \\
\hline 180 & $92.23 \pm 0.52^{\mathrm{a}}$ & $1.69 \pm 0.29^{\mathrm{a}}$ & $15.05 \pm 0.66^{\mathrm{a}}$ & $2.82 \pm 1.04^{\mathrm{a}}$ & $20.15 \pm 1.42^{\mathrm{a}}$ & $0.50 \pm 0.00^{\mathrm{c}}$ & $220.00 \pm 0.67^{\mathrm{a}}$ \\
\hline
\end{tabular}

Data on all analyses are means \pm standard deviations of triplicate determination. Within the same column, different superscripts are significantly different at $\mathrm{p} \leq 0.05$, as measured by Tukey's test. Abbreviations: $\%=$ percent, $\mathrm{L}^{*}=\mathrm{degree}$ of lightness, $\mathrm{a}^{*}=$ degree of redness, $\mathrm{b}^{*}=$ degree of yellowness, $\mathrm{g} / \mathrm{mL}=$ gram per milliliter, $\mathrm{g} / 100 \mathrm{~g}=\mathrm{gram}$ per $100 \mathrm{~g},{ }^{\circ} \mathrm{C}=$ degree Celcius and secs $=$ seconds.

The bulk density of the spray-dried 'Bintangor' orange powder ranged from $0.46 \pm 0.00 \mathrm{~g} / \mathrm{mL}$ to $0.50 \pm 0.01 \mathrm{~g} / \mathrm{mL}$. The lowest bulk density was achieved by the spray-dried powder at inlet temperature $160^{\circ} \mathrm{C}$, while the highest bulk density was achieved by the powder that spray-dried at $170^{\circ} \mathrm{C}$. The bulk density of the spray-dried powder at inlet temperature $140^{\circ} \mathrm{C}$ and $150^{\circ} \mathrm{C}$ increased from $0.48 \pm 0.01 \mathrm{~g} / \mathrm{mL}$ to $0.49 \pm 0.00 \mathrm{~g} / \mathrm{mL}$. While the bulk density of the powder spray-dried at $180^{\circ} \mathrm{C}$ was $0.50 \pm 0.00 \mathrm{~g} / \mathrm{mL}$, which is less than the bulk density of powder that is spray-dried at inlet temperature $170^{\circ} \mathrm{C}$.
From the finding of other studies, it was found that increasing inlet temperature causes the bulk density of the spray-dried powder to decrease (Cai and Corke, 2000; Chegini and Ghobadian, 2007; Tuyen et al., 2010). This reduction was due to evaporation rates are faster and products dry to a more porous or fragmented structure when the inlet temperature increases (Goula and Adamopoulos, 2005). Hence, it can be said the optimum inlet temperature with optimum maltodextrin concentration for the spray-drying of 'Bintangor' orange powder is $170^{\circ} \mathrm{C}$ with $20 \%$ maltodextrin concentration. 


\subsection{Reconstitution of optimized 'Bintangor' orange powder}

The optimized reconstituted powder was compared with the 'Bintangor' orange juice in Table 4. The reconstituted powder was darker (with a reduction in $\mathrm{L}^{*}$ value). In addition, the yellow and red values were lesser as compared to the fresh 'Bintangor' orange juice. This may be due to browning reactions occurring during spray-drying and maltodextrin addition (Jittanit et al., 2010). The viscosity of the optimized reconstituted powder was $2.92 \pm 0.22 \mathrm{cP}$, while the viscosity of the 'Bintangor' orange juice was $4.87 \pm 0.60 \mathrm{cP}$.

The difference between the TSS of the optimized reconstituted powder and
'Bintangor' orange juice might due to the optimized powder produced at high temperature was increased in particle size. The particles produced were uneven in size. Powder with larger size will sink while smaller size particles are dusty and resulted in uneven wetting and reconstitution (Fazaeli et al., 2012). The $\mathrm{pH}$ of the optimized reconstituted powder was $4.20 \pm 0.02$, which was slightly lower than the $\mathrm{pH}$ of the 'Bintangor' orange juice with $\mathrm{pH}$ $4.29 \pm 0.03$. This difference may be the result of concentration accompanied by the release of sugars and acids from maltodextrin during drying (Patil et al., 2014).

Table 4. Physicochemical analyses of 'Bintangor' orange juice and optimized reconstituted powder

\begin{tabular}{|c|c|c|}
\hline Analyses & $\begin{array}{c}\text { 'Bintangor' orange } \\
\text { juice }\end{array}$ & $\begin{array}{c}\text { Optimized reconstituted } \\
\text { powder }\end{array}$ \\
\hline Color $\left(\mathrm{L}^{*}\right)$ & $47.92 \pm 1.46^{\mathrm{a}}$ & $37.16 \pm 0.26^{\mathrm{b}}$ \\
\hline Color (a*) & $10.44 \pm 0.33^{\mathrm{a}}$ & $-3.28 \pm 0.37^{\mathrm{b}}$ \\
\hline Color (b*) & $38.53 \pm 0.88^{\mathrm{a}}$ & $15.03 \pm 1.85^{\mathrm{b}}$ \\
\hline Viscosity (cP) & $4.87 \pm 0.60^{\mathrm{a}}$ & $2.92 \pm 0.22^{\mathrm{b}}$ \\
\hline TSS ( ${ }^{\circ}$ Brix) & $12.00 \pm 0.35^{\mathrm{a}}$ & $11.67 \pm 0.25^{\mathrm{b}}$ \\
\hline $\mathrm{pH}$ & $4.29 \pm 0.03^{\mathrm{a}}$ & $4.20 \pm 0.02^{\mathrm{b}}$ \\
\hline
\end{tabular}

Data on TSS, $\mathrm{pH}$, viscosity, and color are means \pm standard deviations of triplicate determination. Abbreviations: TSS $=$ total soluble solid, ${ }^{\circ}$ Brix $=$ degree Brix, $\mathrm{pH}=$ potential of hydrogen, $\mathrm{cP}=$ centipoise, $\mathrm{L}^{*}=$ degree of lightness and darkness, $\mathrm{a}^{*}=$ degree of redness or greenness and $\mathrm{b}^{*}=$ degree of yellowness or blueness.

\subsection{Proximate analyses spray-dried 'Bintangor' orange powder}

The proximate analyses of spray-dried 'Bintangor' orange powder are shown in Table 5. There was no ash content had been observed. Besides that, the fat content and the protein content of the 'Bintangor' orange powder were $2.21 \pm 1.91 \%$ and $2.44 \pm 0.00 \%$, respectively. The fat and protein content of the 'Bintangor' orange powder was very low. As compared to the spray-dried sweet potato powder, the ash content of the spray-dried 'Bintangor' orange powder was much lower than the ash content of spray-dried sweet potato powder, which is 2.4 $\mathrm{g} / 100 \mathrm{~g}$ (Grabowski et al., 2008). While for the protein and fat content, the fat and protein content of the 'Bintangor' orange powder is higher than the berry powders (strawberries, blueberries, raspberries, and blackberries). The fat content of berries fruit powder was ranged from $0.30 \%$ to $1.00 \%$ while the protein content for berries fruit powder was ranged from $0.60 \%$ to $1.30 \%$ (Khalloufi et al., 2000). 
Table 5. Proximate analyses of spray-dried 'Bintangor' orange powder

\begin{tabular}{|c|c|}
\hline Properties & Values (\%) \\
\hline Ash & $0.00 \pm 0.00$ \\
\hline Fat & $2.21 \pm 1.91$ \\
\hline Protein & $2.44 \pm 0.00$ \\
\hline
\end{tabular}

Data on ash, fat, and protein are means \pm standard deviations of triplicate determination. Abbreviations: $\mathrm{g} / 100 \mathrm{~g}=\mathrm{gram}$ per $100 \mathrm{~g}$ and $\%=$ percent.

\section{Conclusions}

'Bintangor' orange is believed to be the hybrid between a common mandarin and bitter orange. This research study was conducted to produce 'Bintangor' orange powder through the spray-drying process, with different maltodextrin concentration and different inlet temperatures. The water activity of spray-dried powder was decreased with the addition of maltodextrin ( 5 to $15 \% \mathrm{w} / \mathrm{w}$ ), with no further decrease from $15 \%(\mathrm{w} / \mathrm{w})$ to $25 \%(\mathrm{w} / \mathrm{w})$. In contrast, moisture content decreased with an increase of maltodextrin concentration. With an increase in maltodextrin concentration, the powder produced was lighter, less yellow and less reddish. Also, hygroscopicity and wettability of spray-dried powder reduced with an increase from $5 \%(\mathrm{w} / \mathrm{w})$ maltodextrin concentration to $25 \% \quad(\mathrm{w} / \mathrm{w})$ maltodextrin concentration. Generally, the properties of 'Bintangor' orange powder were not affected by the increase of inlet temperature. It can be concluded that the production of 'Bintangor' orange powder is optimized at inlet temperature at $170^{\circ} \mathrm{C}$ with a $20 \%(\mathrm{w} / \mathrm{w})$ concentration of maltodextrin.

\section{References}

Angel, R.C.M., Espinosa-Muñoz, L.C., AvilesAviles, C., González-García, R., MoscosaSantillán, M., Grajales-Lagunes, A., AbudArchila, M. (2009). Spray-drying of passion fruit juice using lactosemaltodextrin blends as the support material. Brazilian Archives of Biology and Technology, 52(4), 1011-1018.

AOAC, I. (2000). AOAC official methods of analysis.

Cai, Y.Z., Corke, H. (2000). Production and properties of spray-dried Amaranthus betacyanin pigments. Journal of Food Science, 65(7), 1248-1252.

Chang, L.S., Tan, Y.L., Pui, L.P. (2020). Production of spray-dried enzymeliquefied papaya (Carica papaya L.) powder. Brazilian Journal of Food Technology, 23. e2019181.

Chang, L.S., Yong, S.M.E., Pui, L.P. (2020). Production of spray-dried "Terung Asam" (Solanum lasiocarpum Dunal) Powder. Walailak Journal of Science and Technology (WJST), in press.

Chauhan, A.K., Patil, V. (2013). Effect of packaging material on storage ability of mango milk powder and the quality of reconstituted mango milk drink. Powder Technology, 239, 86-93.

Chegini, G.R., Ghobadian, B. (2007). Spray dryer parameters for fruit juice drying. World Journal of Agricultural Sciences, 3(2), 230-236.

Chew, S., Tan, C., Pui, L., Chong, P., Gunasekaran, B., Nyam, K. (2019). Encapsulation technologies: A tool for functional foods development. International Journal of Innovative Technology and Exploring Engineering, 8(5S), 154-160.

Chng, G.Y.V., Chang, L.S., and Pui, L.P. (2020). Effects of maltodextrin concentration and inlet temperature on the physicochemical properties of spray-dried kuini powder. Asia Pacific Journal of Molecular Biology and Biotechnology, 28(4),113-131.

Chukwuka, K.S., Okonko, I.O., Adekunle, A.A. (2010). Microbial ecology of organisms causing pawpaw (Carica papaya L.) fruit decay in Oyo State, 
Nigeria. American-Eurasian Journal of

Toxicological Sciences, 2(1), 43-50.

Cortés, C., Esteve, M.J., Frígola, A. (2008). Color of orange juice treated by high intensity pulsed electric fields during refrigerated storage and comparison with pasteurized juice. Food Control, 19(2), 151-158.

Fazaeli, M., Emam-Djomeh, Z., Ashtari, A.K., Omid, M. (2012). Effect of spray drying conditions and feed composition on the physical properties of black mulberry juice powder. Food and Bioproducts Processing, 90(4), 667-675.

Ferrari, C.C., Germer, S.P.M., Alvim, I.D., Vissotto, F.Z., de Aguirre, J.M. (2012). Influence of carrier agents on the physicochemical properties of blackberry powder produced by spray drying. International Journal of Food Science \& Technology, 47(6), 1237-1245.

Gan, W.S., Lew, Y.Y., Thor, S.Y., Chng, G.Y.V.,Yusof, Y.A., Pui, L.P. (2021). Effects of drying methods on the physicochemical properties and antioxidant capacity of Kuini powder. Brazilian Journal of Food Technology, in press.

Gopinathan, M., Yusof, Y.A., \& Pui, L.P (2020). Effects of different drying methods on the physicochemical and antioxidant content of 'cempedak' (Artocarpus integer L.) powder. Journal of Food Processing and Preservation, 00, e14966.

Goula, A.M., Adamopoulos, K.G. (2010). A new technique for spray drying orange juice concentrate. Innovative Food Science \& Emerging Technologies, 11(2), 342-351.

Goula, A.M., Adamopoulos, K.G. (2005). Spray drying of tomato pulp in dehumidified air: II. The effect on powder properties. Journal of Food Engineering, 66(1), 35-42.

Grabowski, J.A., Truong, V.D., Daubert, C.R. (2006). Spray-drying of amylase hydrolyzed sweetpotato puree and physicochemical properties of powder. Journal of Food Science, 71(5), E209-E217.

Grabowski, J.A., Truong, V.D., Daubert, C.R. (2008). Nutritional and rheological characterization of spray dried sweetpotato powder. LWT-Food Science and Technology, 41(2), 206-216.

Hui, Y.H., Chen, F., Nollet, L.M., Guiné, R.P., Martín-Belloso, O., Mínguez-Mosquera, M.I., Paliyath, G., Pessoa, F.L., Le Quéré, J.L., Sidhu, J.S., Sinha, N. eds. (2010). Handbook of fruit and vegetable flavors. New Jersey: John Wiley and Sons.

Jackson, D., Looney, N.E., Morley-Bunker, M. eds. (2011). Temperate and subtropical fruit production. Cambride: CABI.

Jenks, M.A., Bebeli, P. eds. (2011). Breeding for fruit quality. Oxford: John Wiley \& Sons.

Jittanit, W., Niti-Att, S., Techanuntachaikul, O. (2010). Study of spray drying of pineapple juice using maltodextrin as an adjunct. Chiang Mai Journal of Science, 37(3), 498-506.

Karel, M., Lund, D.B. (2003). Physical principles of food preservation: revised and expanded (Vol. 129). New York: CRC Press.

Khalloufi, S., El-Maslouhi, Y., Ratti, C. (2000). Mathematical model for prediction of glass transition temperature of fruit powders. Journal of Food Science, 65(5), 842-848.

Ladanyia, M., Ladaniya, M. (2010). Citrus fruit: biology, technology and evaluation. London: Academic press.

Laszlo, P. (2008). Citrus: A history. Chicago: University of Chicago Press.

Loo, Y. Y., Pui, L.P. (2020). Storage stability of kuini (Mangifera odorata) powder in aluminum laminated polyethylene and polyethylene terephthalate. Malaysian Journal of Analytical Sciences, 24(5), 657 - 669.

Patil, V., Chauhan, A.K., Singh, R.P. (2014). Optimization of the spray-drying process for developing guava powder using 
response surface methodology. Powder Technology, 253, 230-236.

Phisut, N. (2012). Spray drying technique of fruit juice powder: some factors influencing the properties of product. International Food Research Journal, 19(4), 1297-1306.

Phoungchandang, S., Sertwasana, A. (2010). Spray-drying of ginger juice and physicochemical properties of ginger powders. Science Asia, 36(1), 40-45.

Pui, L.P., Karim, R., Yusof, Y.A., Wong, C.W., Ghazali, H.M. (2018). Physicochemical and sensory properties of selected 'cempedak' (Artocarpus integer L.) fruit varieties. International Food Research Journal, 25(2), 861-869.

Pui, L.P., Karim, R., Yusof, Y.A., Wong, C.W., Ghazali, H.M. (2020a). Optimization of spray-drying parameters for the production of 'Cempedak' (Artocarpus integer) fruit powder. Journal of Food Measurement and Characterization, 14(6), 3238-3249.

Pui, L.P., Karim, R., Yusof, Y.A., Wong, C.W., Ghazali, H.M. (2020b). Anti-caking agent effects on the properties of spray-dried 'cempedak' fruit powder. Journal of Tropical Agricultural Science, 43(4), 621635.

Pui, L.P., Karim, R., Yusof, Y.A., Wong, C.W., Ghazali, H.M. (2021). Effects of spraydrying parameters on powder flow and reconstitution properties of spray-dried 'cempedak. Acta Scientiarum Polonorum Technologia Alimentaria, in press.

Quek, S.Y., Chok, N.K., Swedlund, P. (2007). The physicochemical properties of spraydried watermelon powders. Chemical Engineering and Processing: Process Intensification, 46(5), 386-392.

Rizza, R.A. ed. (2002). Encyclopedia of foods: A guide to healthy nutrition. California: Academic Press.

Roussos, P.A., Paziodimou, C., Kafkaletou, M. (2011). Assessment of twenty-two citrus cultivars (oranges, mandarins and lemons) for quality characteristics and phytochemicals concentration. Acta Horticulturae 981, 657-663.

Sinha, N., Sidhu, J., Barta, J., Wu, J., Cano, M.P. eds. (2012). Handbook of fruits and fruit processing. Oxford: John Wiley \& Sons.

Tonon, R.V., Brabet, C., Hubinger, M.D. (2010). Anthocyanin stability and antioxidant activity of spray-dried açai (Euterpe oleracea Mart.) juice produced with different carrier agents. Food Research International, 43(3), 907-914.

Tonon, R.V., Freitas, S.S., Hubinger, M.D. (2011). Spray drying of açai (Euterpe oleraceae Mart.) juice: effect of inlet air temperature and type of carrier agent. Journal of Food Processing and Preservation, 35(5), 691-700.

Tuyen, C.K., Nguyen, M.H., Roach, P.D. (2010). Effects of spray drying conditions on the physicochemical and antioxidant properties of the Gac (Momordica cochinchinensis) fruit aril powder. Journal of Food Engineering, 98(3), 385-392.

Urgi.versailles.inra.fr. (2020). GnpIS - Taxon: (Citrus reticulata Blanco $\mathrm{x}$ Citrus aurantium L.). [online] Retrieved from: https://urgi.versailles.inra.fr/sequence/com mon/card.do;jsessionid=DD7FA22B78A7 D8D18EA14FD6567F4B4A? id=5360\&db Name $=$ common \&className $=$ genres. taxon omy.TaxonImpl [Accessed: 22 Mar 2020].

Wong, C.W., Pui, L.P., Ng, J.M.L. (2015). Production of spray-dried Sarawak pineapple (Ananas comosus) powder from enzyme liquefied puree. International Food Research Journal, 22(4), 1631-1636. 